\title{
Preliminary study on the effect of nitrogen fertilization on growth quality of Gynura procumbens
}

\author{
Mohamad Fhaizal Mohamad Bukhori ${ }^{\mathrm{a}, \mathrm{b}^{*}}$, Hawa Z. E. Jaafar ${ }^{\mathrm{a}}$, Ali Ghasemzadeh ${ }^{\mathrm{a}}$, Uma Rani Sinniah ${ }^{\mathrm{a}}$ \\ ${ }^{a}$ Department of Crop Science, Faculty of Agriculture, Universiti Putra Malaysia, Serdang 43400, Selangor, Malaysia \\ ${ }^{b}$ Centre for Pre-University Studies, Universiti Malaysia Sarawak, 94300 Samarahan, Sarawak, Malaysia
}

Received 30th October 2020 / Accepted 28th December 2020

\begin{abstract}
G. procumbens is an herbaceous medicinal plant. Despite the progressive reports on the potential pharmacological properties, many are overlooking at the importance of its agronomic requirements, especially in fertilization to produce high yields which have not been conclusively concluded. This study was carried out to examine the effects of nitrogen on growth quality. In this study of two factors, harvesting times and rate of nitrogen, a total of 12 combined treatments replicated three times with 108 plants were laid out according to randomized complete block design. Growth attributes were recorded in three harvests of triplicate samples to exhibit the trend for plant growth and quality, and statistically analysed. Nitrogen affected plant growth significantly $(p \leq 0.05)$ with stronger effect on physiological attributes $(p \leq 0.01)$. The results suggested that 0 nitrogen $\mathrm{kg} / \mathrm{ha}$ at Week 12 and 90 nitrogen $\mathrm{kg} / \mathrm{ha}$ at Week 4 is highly and least, respectively affected the morphology and physiology of $G$. procumbens. These attributes are controlled by the availability of usable nitrogen and agronomic management because nitrogen is needed in optimum quantity and must be in balance with other nutrients to achieve its maximum yield potential.
\end{abstract}

Keywords: biomass, growth, Gynura, nitrogen, physiology

\section{INTRODUCTION}

Gynura procumbens (G. procumbens) is one of the important herbaceous plants in Malaysia (Mustaffa et al., 2011). In recent years, the public interest on this on this plant has been increased considerably, due to its medicinal properties (Sekar et al., 2014). The leaves contain major biochemical constituents such as flavonoid, phenolic, alkaloids, saponins, anthraquinone glycosides and volatile oils; with the active compounds, kaempferol-3-O-glucoside (7.33\%) and phenolic acid (7.20\%) (Mou \& Dash, 2016). The total percentage of active biochemical compounds has been reported at $1.60 \%$ to $13.22 \%$ (Morat, 2013). The production of plantbased medicinal compounds is however

*Author for correspondence: Mohamad Fhaizal Mohamad Bukhori, Department of Crop Science, Faculty of Agriculture, Universiti Putra Malaysia, Serdang 43400, Selangor, Malaysia. Email mbmfhaizal@preuni.unimas.my associated to the quality of plant material, the climate and general agronomic management. Not just the growth, but the compound contents are influenced by the plants growing environment (Caretto et al., 2015). This includes fertilizer availability and uptake, which pose as one of the major factors determining productivity in agriculture. The optimum rates of fertilizer are important to ensure the growth enhancement of the plant. Adequate supply of fertilizer, especially nitrogen $(\mathrm{N})$, is important for optimal growth and biomass production. Nitrogen is an essential macronutrient and interactive factor which has significant role in driving photosynthesis, growth and resource affecting secondary metabolite 
content. This is because, $\mathrm{N}$ is part of the chlorophyll and protein synthesis constituent (Chen et al., 2013; Ibrahim et al., 2012). The growth of plants, such as number of leaves, leaf area, stem height, and leaf gas exchange, can be improved by optimising $\mathrm{N}$ rates (Kaiser et al., 2016). These changes in growth and physiology, however, have not been comprehensively documented for $G$. procumbens. Therefore, this study aimed to determine the effect of $\mathrm{N}$ on the growth of $G$. procumbens. The general objective of this study is to examine the effects of different rates of $\mathrm{N}$ on growth and physiology responses of G. procumbens. The specific objectives of this study were to determine the effects of different rates of $\mathrm{N}$ on the growth and physiology at different ages presented by the growth and physiology of $G$. procumbens at different ages [different harvesting $(\mathrm{H})$ times], and to identify the optimum harvesting times for biomass (harvest index).

\section{MATERIALS AND METHODS}

\section{Experimental design and treatments}

The experiment was based on Randomized Complete Block Design (RCBD). The data was processed using the analysis of variance (ANOVA) and mean differences analysed using Duncan Multiple Range Test (DNMRT) and Pearson's Correlation Coefficients (PCC), SAS ${ }^{\circledR}$ 9.4 software (Version 8.0, SAS Institute Inc., and Cary, USA.) This experiment was two-factorial experiment. The first factor was four rates of $\mathrm{N}$ at 30 (N30), 60 (N60), 90 (N90) $\mathrm{kg} \mathrm{N} / \mathrm{ha}$ and a control without $\mathrm{N}$ application (N0), which corresponds to respective $\mathrm{g} /$ plant applications of $0.36 \mathrm{~g}, 0.72 \mathrm{~g}, 1.08 \mathrm{~g}$ and $0 \mathrm{~g} / \mathrm{plant}$, applied in the form of urea (Agrenas, Malaysia) (Hanudin et al., 2012). The $\mathrm{N}$ was split into three fertilization phases (three months), and each phase (each month) was about $33.3 \%$ of total $\mathrm{N}$ applied at the first week of the month. The second factor was plant age at three $\mathrm{H}$ times, viq. 4, 8 and 12 weeks after treatments, WAT.

\section{Plant preparation}

The mother plants were obtained from the nursery collection and sent for identification in Institute of Bioscience, Universiti Putra Malaysia, voucher specimen (SK 2681/15). The propagation was conducted using cutting from mature stem $(10 \mathrm{~cm}, \geq 2$ internode) and placed in the seed tray containing uniform mixture of sand: coco-peat $(1: 1 \mathrm{v} / \mathrm{v})$ ratio (Fengling Agro-Tech, Malaysia), for rooting purposes (Awang et al., 2009). The regenerated plants (1 month old) were then transferred into polyethylene bags $(25 \mathrm{~cm}$ diameter) containing uniform mixture of soilless medium of coco-peat: burnt paddy husk: well composted chicken manure $(5: 5: 1 \mathrm{v} / \mathrm{v} / \mathrm{v})$ ratio (Fengling Agro-Tech, Malaysia), and left for a month to acclimatize until ready for the treatments (Jaafar et al., 2012). The growing media was at $\mathrm{pH}$ value 5.5 to 7.0 (S20 SevenEasy, METTLER Toledo, USA). The greenhouse average temperatures were at 22.9 to $27.2^{\circ} \mathrm{C}$ with relative humidity between 50 and $70 \%$. Meanwhile, the average daytime irradiance was $500 \mu \mathrm{mol} \mathrm{m} \mathrm{m}^{-2} \mathrm{~s}^{-1}$ photosynthetic active radiation (LQM50-3, Apogee Instruments Inc., USA).

\section{Maintenance and sampling}

The plants were watered manually once a day in the morning or when necessary. If temperature was higher than $33^{\circ} \mathrm{C}$, watering was conducted twice or thrice. Each watering was about $500 \mathrm{~mL}$ per plant. Non-chemical pest and disease control was conducted manually at the sight of their presence. Each combined treatment consisted of 27 plants totalling a sum of 108 plants used in the experiment. Three plants per treatment were sampled at each harvest time.

\section{Total plant dry weight}

The plants were harvested randomly and separately at 4, 8 and 12 WAT. Immediately after harvesting, the plants were cleaned and separated into leaves, stems, and roots manually. Fresh plant materials were weighed, and transferred to labelled paper bags and then dried at $40^{\circ} \mathrm{C}$ in forced draft oven (UFB 400, Memmert, Germany) until constant weight attained to obtain dry weight, g, (TPDW) (Oyedeji et al., 2014). The biomass of the dry weight was measured using two-decimal point electronic weighing machine (B303-S college, METTLER TOLEDO, USA). Measurements were obtained by averaging three measurements. Dried samples were ground to fine powder $(0.25 \mathrm{~mm})$ using grinder (1093 
CYCLOTEC, FOSS TECATOR, USA) and kept in pill box at room temperature until analysis.

\section{Plant height}

The height, $\mathrm{cm},(\mathrm{PH})$ was measured manually using straight scale. The $\mathrm{PH}$ indicates the value between the apex (top) and the lowest stem part. Measurements were obtained by averaging three measurements (Perkasa et al., 2016).

\section{Number of leaves and total leaf area}

Prior to leaf drying, number of leaves (NoL) was counted manually (Oyedeji et al., 2014). Then, the total area of fresh leaves, $\mathrm{cm}^{2}$, (TLA) was measured using leaf area meter $\left(\right.$ LI-COR ${ }^{\circledR}$ LI3100 , USA). Three measurements were done by placing the leaf on the automatically conveyer belts rotated to move leaves across a scanning bed, enabling collection of data from the same plant by recording the area of individual leaves and quickly computes cumulative area for a group of leaves. Measurements were obtained by averaging three measurements (An \& Shangguan, 2008).

\section{Photosynthetic rate and stomatal conductance rate}

The measurement was obtained from LI-COR ${ }^{\circledR}$ Environmental with closed infrared gas analyzer (LI-6400XT, Portable Photosynthesis System, USA). The measurements were carried out between 09:00 to 11:00 a.m. using fully expanded third and fourth young leaves numbered three and four from plant apex to record photosynthetic carbon assimilation rate (Photo) and stomatal conductance to water rate (Cond). The operation was automatic, and the data were stored in LI6400 console and analyzed by the Photosyn Assistant software. Plants of the different treatments were measured alternately. (Ibrahim $e t$ al., 2017b).

\section{Total chlorophyll contents}

Total chlorophyll content (TChlC) was measured using fresh weight basis. Only fresh leaf tissues of the third fully expanded leaves from the top of an individual plant were used in the analysis. Leaf disk of $3 \mathrm{~mm}$ in diameter was obtained using puncher to acquire 15 consistent sizes per treatment per block. The leaf disks were immediately immersed and incubated in $20 \mathrm{~mL}$ of $80 \%$ acetone $\left(\right.$ EMSURE $^{\circledR}$ MERCK, USA) for homogenization in an aluminum foil-covered glass bottle for approximately $24 \mathrm{~h}$ at $5^{\circ} \mathrm{C}$ until all the green colour had bleached out. Finally, the solution $(15 \mu \mathrm{L})$ was transferred into 96 well plate to determine absorbances of chlorophyll a (Chl a), b (Chl b), and carotenoids (Car) using UV-vis Spectrophotometer at wavelengths of 645,662 and $470 \mathrm{~nm}$ (MULTISKAN GO Version 1.00.40, Thermo Fisher SCIENTIFIC, USA), respectively. Measurements were run in three replicates. The chlorophyll content was calculated as $\mu \mathrm{g} \mathrm{g}^{-1}$ fresh weight as per standard equations recommended (Ibrahim et al., 2017a).

$$
\begin{aligned}
\text { Chl } a & =[(12.47 \times \text { OD at 662) }-(3.62 \times \text { OD at } 645) \times 10] /(1000 x w t) \\
\text { Chl } b & =[(25.06 \times \text { OD at } 645)-(6.50 \times \text { OD at } 662) \times 10] /(1000 x w t) \\
\text { Car } & =[(1000 x \text { OD at } 4700-(1.29 \times \text { Chl a })-(53.78 \times \text { Chl b })] / 220
\end{aligned}
$$

\section{Statistical analysis}

The data were subjected to ANOVA and correlation using SAS ${ }^{\circledR} 9.4$ software (Version 8.0, SAS Institute Inc., and Cary, USA.). The analysis were done in triplicate and expressed as mean $(n=3) \pm$ standard error (SE) from the dependent treatments (Jaafar et al., 2012). The variables from measurements were analyzed using General Linear Model with N supply managements. Any differences between treatment means were analysed by two-way analysis and compared using DMRT at $\mathrm{p}$ value $\leq 0.05$ levels. The regression model that best fitted the data, evaluated by an $\mathrm{F}$ test, was chosen.

\section{RESULTS}

\section{Total plant dry weight}

The TPDW was statistically decreased with increasing rates of $\mathrm{N}$ and increased with increasing $\mathrm{H}$ times $(p \leq 0.05)$ (Figure $1 \mathrm{a}$ and Tables 1 and 2). The N90 treatment has an overall lower 
TPDW in comparison to control treatment (N0) at all $\mathrm{H}$ times. Total plant dry weight was highest in $\mathrm{N} 0$ at Week 12 compared to the highest $\mathrm{N}$ rate (N90) at Week 4. Meanwhile, N30 has higher TPDW than $\mathrm{N} 0$ at Week 12. In this study, biomass increased (significant, $p \leq 0.0001$ ) with continuing $\mathrm{H}$ times, however, declined progressively (not significant, $p \geq 0.05$ ) with rising $\mathrm{N}$ rate (Figure 1a).

Table 1. Probability of greater $\mathrm{F}(\mathrm{P}>\mathrm{F})$ for the ANOVA on effect of nitrogen rates and harvest times on growth and physiology variables.

\begin{tabular}{|l|c|c|c|c|}
\hline Source & $\mathbf{N}$ & $\mathbf{H}$ & $\mathbf{N} \mathbf{x} \mathbf{H}$ & $\mathbf{C o V}$ \\
\hline Df & 3 & 2 & 6 & \\
\hline TPDW & $\mathrm{ns}$ & $* * * *$ & $\mathrm{~ns}$ & 62.405 \\
\hline PH & $* * * *$ & $* * * *$ & $* * * *$ & 10.095 \\
\hline NoL & $* *$ & $* * *$ & $*$ & 21.198 \\
\hline TLA & $* * *$ & $* * * *$ & $\mathrm{~ns}$ & 32.457 \\
\hline Photo & $* * * *$ & $* * * *$ & $* * * *$ & 2.866 \\
\hline Cond & $* * * *$ & $* * * *$ & $* * * *$ & 3.638 \\
\hline TCh1C & $* * * *$ & $* * * *$ & $* * * *$ & 0.609 \\
\hline
\end{tabular}

All analyses are mean \pm standard error of mean, $\mathrm{N}=36$ using DMRT. * Significant at $\mathrm{p} \leq 0.05, * *$ Significant at $\mathrm{p} \leq 0.01$, *** Significant at $\mathrm{p} \leq 0.001, * * * *$ Significant at $\mathrm{p} \leq 0.0001$, ns Not significant at $\mathrm{p} \geq 0.05, \mathrm{~N}=$ Nitrogen rates, $\mathrm{H}=$ Harvest times, $\mathrm{CoV}=$ Coefficient of variation, $\mathrm{Df}=$ Degree of freedom, TPDW=Total plant dry weight, $\mathrm{PH}=$ Plant heights, NoL $=$ Number of leaves, TLA $=$ Total leaf area, Photo $=$ Photosynthetic rate, Cond $=$ Stomatal conductance rate, and $\mathrm{TChlC}=$ Total chlorophyll content.

\section{Plant height}

Plant height was significantly affected by the interaction of $\mathrm{N}$ and $\mathrm{H}$ times, and by each factor $(\phi \leq 0.0001)$ (Figure $1 \mathrm{~b}$ and Tables 1 and 2). The lowest PH $(17 \mathrm{~cm})$ was found in N30 at Week 4 but increased to $30 \mathrm{~cm}$ at Week 8 . At Week 12, the $\mathrm{PH}$ of plants was increased by $88 \%$. Meanwhile, other treatments (N0, N60, and N90) displayed almost similar height (Figure 1b). Measurements of $\mathrm{PH}$ were significantly correlated with TPDW at $\mathrm{r}=0.730 ; p \leq 0.0001$ by a linear function (Table 3).

\section{Number of leaves}

The NoL in all treatments was increased with the increasing harvesting times including the control treatment $(\mathrm{N} 0)(p \leq 0.05)$ (Figure 1c and Tables 1 and 2). Although the N90 treatment produced high NoL at Week 4, it remained the lowest NoL $(p \leq 0.05)$ in all tested treatments. This inherent variability caused by the random error in the production system of $\mathrm{N}$ fertilization treatment. The NoL was highest in N60 (69) at Week 12. Meanwhile, at Week 4, NoL was significantly higher $(p \leq 0.001)$ in $\mathrm{N} 0$ compared to other treatments. As the plant grew to Weeks 8 and 12, NoL in N30 (39 NoL) had surpassed NoL in N0 (37 NoL). Although the NoL of N30 was lowest (23) ( $\mathrm{p}=\mathrm{ns})$ at Week 4 , it had significantly $(p \leq 0.01)$ increased at Week 12 (54 NoL) (Figure 1c), whereas the NoL of $\mathrm{N} 90$ remained low at Week 8 and Week 12. Measurements of $\mathrm{NoL}$ were significantly correlated with TPDW at $\mathrm{r}=0.688$; $p \leq 0.0001$ by a linear function (Table 3). Obviously, when plants become mature (Week $12)$, the NoL of plant was significantly $(\phi \leq 0.0001)$ higher than younger plants of all treatments.

Table 2. Effect of nitrogen rates and harvest times on growth and physiology variables.

\begin{tabular}{|c|c|c|c|c|c|c|c|}
\hline & TPDW & $\mathbf{P H}$ & NoL & TLA & Photo & Cond & TChlC \\
\hline \multicolumn{8}{|l|}{$\mathbf{N}$} \\
\hline N0 (Control) & $9.694^{a}$ & $40.500^{b}$ & $45.778^{a}$ & $1047.7^{a}$ & $4.245^{\mathrm{a}}$ & $0.065^{\mathrm{a}}$ & $4.782^{c}$ \\
\hline N30 & $8.794^{a}$ & $44.389^{a}$ & $38.444^{a}$ & $831.4^{a}$ & $3.432^{\mathrm{d}}$ & $0.039 \mathrm{c}$ & $5.007 \mathrm{a}$ \\
\hline N60 & $7.888^{\mathrm{a}}$ & $37.222^{c}$ & $43.556^{a}$ & $920.7^{a}$ & $3.755^{\mathrm{b}}$ & $0.053^{\mathrm{b}}$ & $4.937 \mathrm{~b}$ \\
\hline N90 & $5.317 \mathrm{a}$ & $38.833 \mathrm{bc}$ & $29.000^{\mathrm{b}}$ & $541.2^{\mathrm{b}}$ & $3.630^{c}$ & $0.054^{\mathrm{b}}$ & $4.910^{\mathrm{b}}$ \\
\hline \multicolumn{8}{|l|}{$\mathrm{H}$} \\
\hline Week 4 & $4.924^{b}$ & $22.500^{c}$ & $29.083^{b}$ & $486.1^{b}$ & $8.021^{\mathrm{a}}$ & $0.084^{a}$ & $5.198^{a}$ \\
\hline Week 8 & $4.579 \mathrm{~b}$ & $27.125^{b}$ & $33.167 \mathrm{~b}$ & $611.3^{\mathrm{b}}$ & $1.863^{\mathrm{b}}$ & $0.050^{\mathrm{b}}$ & $4.639 \mathrm{c}$ \\
\hline Week 12 & $14.267^{\mathrm{a}}$ & $71.083^{\mathrm{a}}$ & $55.333^{a}$ & $1408.2^{\mathrm{a}}$ & $1.412^{\mathrm{c}}$ & $0.024^{c}$ & $4.889^{\mathrm{b}}$ \\
\hline \multicolumn{8}{|l|}{ Interaction } \\
\hline $\mathbf{N}$ & $0.296^{\mathrm{ns}}$ & $\leq .0001^{* * * *}$ & $0.002^{* *}$ & $0.005^{* * *}$ & $\leq .0001^{* * * *}$ & $\leq .0001^{* * * *}$ & $\leq .0001^{* * * *}$ \\
\hline $\mathbf{H}$ & $\leq .0001^{* * * *}$ & $\leq .0001^{* * * *}$ & $\leq .0001^{* * * *}$ & $\leq .0001^{* * * *}$ & $\leq .0001^{* * * *}$ & $\leq .0001^{* * * *}$ & $\leq .0001^{* * * *}$ \\
\hline $\mathbf{N} \times \mathbf{H}$ & $0.752^{\mathrm{ns}}$ & $\leq .0001^{* * * *}$ & $0.028^{*}$ & $0.145^{\mathrm{ns}}$ & $\leq .0001^{* * * *}$ & $\leq .0001^{* * * *}$ & $\leq .0001^{* * * *}$ \\
\hline
\end{tabular}



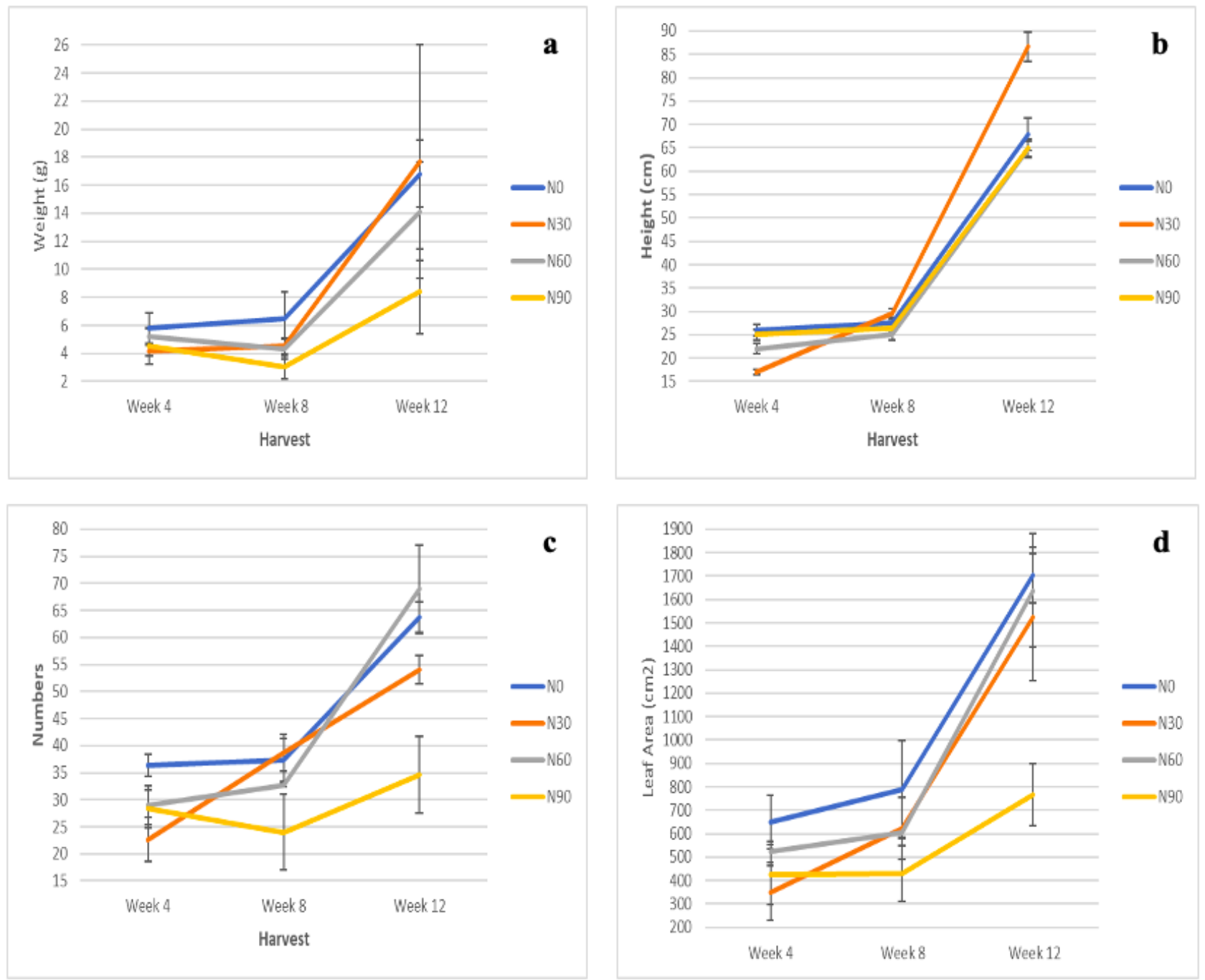

Figure 1. Changes in growth variables in G. procumbens as affected by rates of nitrogen and harvest times. a: Total plant dry weight. b: Plant height. c: Number of leaves. d: Total leaf area. Bars represent standard error of differences between means. $\mathrm{N}=36$.

\section{Total leaf area}

The TLA was significantly lower in N90 treatment compared to other treatments and increased with increasing $\mathrm{H}$ times $(p \leq 0.05)$ due to phenological event (Figure $1 \mathrm{~d}$ and Tables 1 and 2). Total leaf area was highest in $\mathrm{N} 0$ at Week 12 compared to the highest $\mathrm{N}$ rates $(\mathrm{N} 90)$ at Week 4. In this study, $\mathrm{N}$ rates and $\mathrm{H}$ times did not influence TLA significantly ( $p \geq 0.05)$. In N90, TLA was affected significantly $(p \leq 0.05)$ by $48 \%$ compared to other treatments, whilst, at Week 12, TLA was significantly highest $(\phi \leq 0.0001)$ by $65 \%$ compared to the earlier $\mathrm{H}$ times (Figure 1d). Measurements of TLA are significantly correlated with NoL at $r=0.934 ; p \leq 0.0001$ by a linear function (Table 3).

\section{Photosynthetic rate and stomatal conductance rate}

The Photo was affected in all treatments including the control treatment $(\mathrm{N} 0),(p \leq 0.0001)$ (Figure 2a and Tables 1 and 2). The Photo in N0 was highest at Week 4. At Week 8, Photo was significantly $(p \leq 0.0001)$ lower than other treatments. Continuing the treatment to Week 12, the N0 recorded the highest Photo than other treatments at almost $3 \mu \mathrm{mol} \mathrm{CO} \mathrm{Cm}^{-2} \mathrm{~s}^{-1}$. The Photo in N90 treatment was higher than N30 and N60 at Week 12. The N30 has lower Photo compared to N0. Photosynthetic rate was highest in N0 at Week 4 when plants are young and this continued until Week $12(p \leq 0.05)$ followed by N90, N60 and N30 (Figure 2.a). Measurements of Photo are 
significantly correlated with Cond, TPDW, NoL and TLA at $\mathrm{r}=0.860 ; p \leq 0.0001, \mathrm{r}=-0.357 ; p \leq 0.05$, $\mathrm{r}=-0.459 ; \quad p \leq 0.01$ and $\mathrm{r}=-0.489 ; \quad p \leq 0.01$, respectively by a linear function (Table 3 ). This is because Photo was decreased with continuing $\mathrm{H}$ times and increasing $\mathrm{N}$ rate. In this study, Photo was very significantly affected $(p \leq 0.0001)$ by $\mathrm{N}$ rates and $\mathrm{H}$ times. Plants in $\mathrm{N} 0$ displayed significantly highest Photo $(p \leq 0.05)(8.846 \mu \mathrm{mol}$ $\left.\mathrm{CO}_{2} \mathrm{~m}^{-2} \mathrm{~s}^{-1}\right)$ at Week 4 followed by N60 (8.184 $\left.\mu \mathrm{mol} \mathrm{CO} \mathrm{Cm}^{-2} \mathrm{~s}^{-1}\right), \mathrm{N} 30\left(7.601 \mu \mathrm{mol} \mathrm{CO} \mathrm{Cm}^{-2} \mathrm{~s}^{-1}\right)$ and $\mathrm{N} 90\left(7.454 \mu \mathrm{mol} \mathrm{CO} \mathrm{Cm}^{-2} \mathrm{~s}^{-1}\right)$. As plant aged at Week 8 and 12, Photo decreased by $\mathrm{N}$ treatments as follows: N0, N90, N60 and N30 with respective values $0.0510,0.0484,0.0445$ and $0.0407 \mu \mathrm{mol} \mathrm{CO} \mathrm{CO}^{-2} \mathrm{~s}^{-1}$ (Figure 2a).

The Cond was affected in all treatments including the control treatment (N0) and decreased with increasing age indicated by $\mathrm{H}$ times $(p \leq 0.0001)$ (Figure $2 \mathrm{~b}$ and Tables 1 and 2 ). The Cond of plants in N60 treatment recorded highest value $(p \leq 0.05)$ at Week 4 followed by N90, N0 and lowest value in N30. As plant aged,
Cond in N60 was lower than N90 but like N30. Instead, Cond in control treatment (N0) was significantly higher $(p \leq 0.05)$ than other treatments at longer $\mathrm{H}$ times (Week 12). The N30 has lowest Cond compared to N0. Stomatal conductance was highest in N60 at Week 4 compared to N30 at Week 12. Measurements of Cond are significantly correlated with Photo at $\mathrm{r}=0.860 ; p \leq 0.0001$ by a linear function (Table 3). The Cond was highest in N60 at Week 4, and lowest in other treatments especially when plant aged at Week 12 (Figure 2b). Plants in N60 had the lowest intercellular $\mathrm{CO}_{2}$ concentration (232 mol $\mathrm{H}_{2} \mathrm{O} \mathrm{m} \mathrm{m}^{-2} \mathrm{~s}^{-1}$ ) compared to other treatments (N90, $244 \mathrm{~mol} \mathrm{H}_{2} \mathrm{O} \mathrm{m}^{-2} \mathrm{~s}^{-1}$; N0, $296 \mathrm{~mol} \mathrm{H}_{2} \mathrm{O} \mathrm{m}^{-2}$ $\mathrm{s}^{-1}$; and $\mathrm{N} 0,302 \mathrm{~mol} \mathrm{H}_{2} \mathrm{O} \mathrm{m} \mathrm{m}^{-2} \mathrm{~s}^{-1}$ ), which represented higher carbon assimilation and have directly contributed to active Cond $(0.094 \mathrm{~mol}$ $\mathrm{H}_{2} \mathrm{O} \mathrm{m}^{-2} \mathrm{~s}^{-1}$ ) (Figure 2b). Meanwhile, plants in N30 were experiencing diffusion resistance along the study (Selmar \& Kleinwächter, 2013). This finding suggested $\mathrm{N} 0$ is highly stimulated stomatal opening and closing.

Table 3. Correlation of growth and physiology variables.

\begin{tabular}{|c|c|c|c|c|c|c|c|c|}
\hline & $\mathbf{H}$ & TPDW & PH & NoL & TLA & Photo & Cond & TChlC \\
\hline I & 1.000 & & & & & & & \\
\hline 总 & $\begin{array}{c}0.584 \\
* * *\end{array}$ & 1.000 & & & & & & \\
\hline$\stackrel{I}{2}$ & $\begin{array}{l}0.871 \\
* * * *\end{array}$ & $\begin{array}{l}0.730 \\
* * * *\end{array}$ & 1.000 & & & & & \\
\hline 붐 & $\begin{array}{l}0.676 \\
* * * *\end{array}$ & $\begin{array}{l}0.688 \\
* * * *\end{array}$ & $\begin{array}{l}0.722 \\
* * * *\end{array}$ & 1.000 & & & & \\
\hline 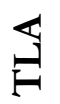 & $\begin{array}{l}0.723 \\
* * * *\end{array}$ & $\begin{array}{l}0.836 \\
* * * *\end{array}$ & $\begin{array}{l}0.799 \\
* * * *\end{array}$ & $\begin{array}{l}0.934 \\
* * * *\end{array}$ & 1.000 & & & \\
\hline$\frac{0}{\stackrel{2}{0}}$ & $\begin{array}{l}-0.884 \\
* * * *\end{array}$ & $\begin{array}{c}-0.357 \\
*\end{array}$ & $\begin{array}{l}-0.600 \\
* * * *\end{array}$ & $\begin{array}{l}-0.459 \\
* * *\end{array}$ & $\begin{array}{c}-0.489 \\
* * *\end{array}$ & 1.000 & & $\begin{array}{l}0.674 \\
* * * *\end{array}$ \\
\hline ن̊̃ & $\begin{array}{c}-0.894 \\
* * * *\end{array}$ & $\begin{array}{l}-0.449 \\
* * *\end{array}$ & $\begin{array}{c}-0.761 \\
* * * *\end{array}$ & $\begin{array}{l}-0.523 \\
* * *\end{array}$ & $\begin{array}{c}-0.549 \\
* * *\end{array}$ & $\begin{array}{l}0.860 \\
* * * *\end{array}$ & 1.000 & $\begin{array}{c}0.261 \\
\mathrm{~ns}\end{array}$ \\
\hline$\underset{H}{\mathcal{U}}$ & & & & & & & & 1.000 \\
\hline
\end{tabular}



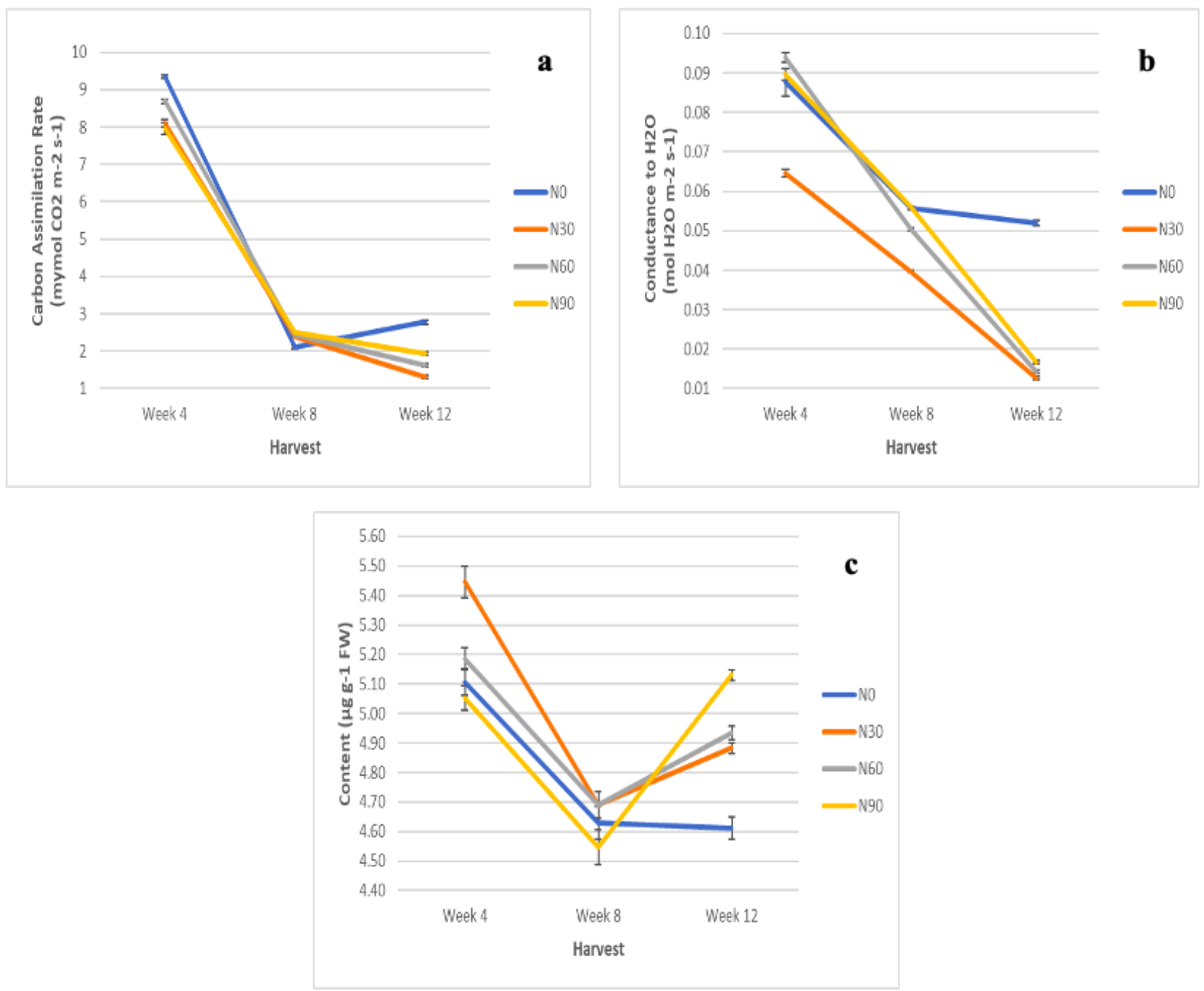

Figure 2. Changes in physiology variables in G. procumbens as affected by rates of nitrogen and harvest times. a: Photosynthetic rate. b: Stomatal conductance rate c: Total chlorophyll content. Bars represent standard error of differences between means. $\mathrm{N}=36$.

\section{Total chlorophyll contents}

The TChlC was statistically affected with increasing rate of $\mathrm{N}$ and age as indicated by the $\mathrm{H}$ times $(p \leq 0.0001)$ (Figure $2 \mathrm{c}$ and Tables 1 and 2 ). At Week 4, the N30 treatment recorded significantly $(\phi \leq 0.0001)$ higher value of TChlC $\left(5.46 \mu \mathrm{g} \mathrm{g}^{-1} \mathrm{FW}\right)$ compared to other treatments. However, at Week 8 all treatments were not significantly different $(p \geq 0.05)$ to each other with the lowest value recorded in N90 treatment (5.06 $\left.\mu \mathrm{g} \mathrm{g}^{-1} \mathrm{FW}\right)$. However, as the plant aged to Week 8 and 12 , the $\mathrm{N} 90$ recorded increased TChlC (5.18 $\left.\mu \mathrm{g} \mathrm{g}^{-1} \mathrm{FW}\right)(p \leq 0.0001)$; followed by N60 (4.90 $\mu \mathrm{g}$ $\left.\mathrm{g}^{-1} \mathrm{FW}\right), \mathrm{N} 30\left(4.88 \mu \mathrm{g} \mathrm{g}^{-1} \mathrm{FW}\right)$ and N0 (4.60 $\mu \mathrm{g} \mathrm{g}^{-}$ $\left.{ }^{1} \mathrm{FW}\right)$. The TChlC in N30 at Week $4\left(5.46 \mu \mathrm{g} \mathrm{g}^{-1}\right.$ FW) was higher than N0 at Week $12\left(4.60 \mu \mathrm{g} \mathrm{g}^{-1}\right.$ FW) (Figure 2c). Measurements of TChlC were significantly correlated with Photo at $\mathrm{r}=0.674$; $p \leq 0.0001$ by a linear function (Table 3 ). The values are concurrent to Photo and Cond rates at Week 4 (Figures $2 \mathrm{a}$ and $2 \mathrm{~b}$ ), where gas exchange rate of leaf was high, and decreased during Week 8 and subsequently increased by $12 \%$ at Week 12 (Figure 2c).

\section{DISCUSSION}

Generally, in this study, all treatments [N0 (control treatment), N30, N60 and N90] did not significantly affect $(p \geq 0.05)$ TPDW of $G$. procumbens which were only influenced by $\mathrm{H}$ times (Figures 1a). Instead all the physiological traits 
(Photo, Cond and TChlC) were markedly influenced by $\mathrm{N}$ treatments, $\mathrm{H}$ times and the interactions between these two factors (Tables 1, 2 , and 3). These effects were due to the requirement of optimal quantity of $\mathrm{N}$ and must be in balance with other fertilizers to achieve its maximum yield potential. Growth-differentiation balance and carbon-nutrient balance hypothesis indicated that $\mathrm{N}$ affected physiological traits (Kleczewski et al., 2010). Based on harvest index analysis, N0 (control treatment) and N90 treatments represent the highest and least effect, respectively on $G$. procumbens growth and physiology traits.

As reported by Davies et al. (2009), N enhanced plant $\mathrm{N}$ content and biomass production successively up to $0.106 \mathrm{~g} / \mathrm{L}$ for biomass and $0.206 \mathrm{~g} / \mathrm{L}$ for leaf $\mathrm{N}$, further increases in $\mathrm{N}$ had no influence. This is because $\mathrm{N}$ is an essential element constituent of plant compounds that determine the quality of plant organic material and also for cell division, enlargement and growth (Mudau et al., 2005). Based on this study, additional rates of $\mathrm{N}$ did not enhance TPDW. High rates of $\mathrm{N}$ can stimulate vegetative growth, but the excessive of $\mathrm{N}$ can reduce plant performance ( $\mathrm{Pal}$ et al., 2015). Measurement of TPDW is a parameter that is best used as an indicator of plant growth by biomass production. This is because total biomass is considered as the embodiment of all processes and events that occur in plant growth. Meanwhile, N30 demonstrated lowest PH at Week 4, however, continuously increased to highest at Week 12 (Figure 1b) because the plant was in conditioning, and $\mathrm{N}$ uptake was slow in the early treatment until the rise start exponentially positive linear to Week 12 ( Perkasa et al., 2016). Biomass increased due to phenological effect (Galieni et al., 2015). Meanwhile, plants in the exponential phase of growth were supplied with $\mathrm{N}$ at four different rates. The $\mathrm{N}$ rate will be accumulated and increased exponentially. As a result, high accumulation of $\mathrm{N}$ forced the plants to grow in linearly increase with their weight. Excessive N, however, reduced the plant performance (Mudau et al., 2005).

For NoL, it was highest in N0 at Week 4 because of stimulation of leaf cell production and expansion due to increasing carbohydrate availability to the plants (Wang et al., 2016).
However, at Week 12, NoL in N0 was lower than that in N60 ( $p \geq 0.05)$, and N30 was surpassed because of alterations in cell growth and proliferation in control plants. The event explained by stress-induced morphogenic response model, which hypothesize in accelerated cell division and formation of more numerous but shorter cells compared to plants in N30 which was in adverse effect (Oyedeji et al., 2014). Meanwhile, N90 produced the lowest NoL (29) throughout $\mathrm{H}$ times $(p \leq 0.05)$ (Figure 1c). This was because of negative impact alleviation of $\mathrm{N}$ rates with respect to plant growth (Ali et al., 2012). The leaf area was increased (significant, $(p \leq 0.0001))$ with continuing $\mathrm{H}$ times, however, did not significantly change with rising $\mathrm{N}$ rates ( $p \geq 0.05$ ). Total leaf area in N0, N30 and N60 was not significantly different $(p \geq 0.05)$ compared to $\mathrm{N} 90$ because of efficiency of $\mathrm{N}$ uptake to the leaf (An \& Shangguan, 2008) (Figure 1d). In the leaf, photosynthetic process occurred will produce energy for plant growth and development. Therefore, insufficient of $\mathrm{N}$ could induce stunted cell division and consequently inhibited plant growth (leaf growth) following ineffective photosynthesis rates (Hanudin et al., 2012).

In this study, Photo and Cond have decreased with increasing $\mathrm{N}$ rate (Figures $2 \mathrm{a}$ and $2 \mathrm{~b}$ ). This is because the plants in $\mathrm{N} 0$ had enough $\mathrm{N}$ from the growth media for higher photosynthetic capacity and light utilisation. Sugggesting N0 is highly respond to nutrient acquisition and significantly affected by water availability and carbon use efficiency (Wang et al., 2016). The Cond seemed to decrease with increasing $\mathrm{N}$ rates especially with increasing $\mathrm{H}$ times probably because of preadaptation, adaptation and post-adaptation during plant growth (Heydarizadeh, 2016). In early stage of growth, stomatal are in pre-adaptation during the acclimatization, therefore Cond was low, following adaptation during the continuous treatment, therefore, Cond was increased, and finally post-adaptation where Cond was decreased during the growth terminal (Wuyts, 2015).

However, in order to maximise the plant biomass, the plant requires optimal Photo and Cond via regulation of $\mathrm{N}$ supply (Ali et al., 2012). It is appropriate to examine the effects of $\mathrm{N}$ (interactive factor over time) in driving photosynthesis and growth (Galieni et al., 2015). This is because $\mathrm{N}$ influence physiological traits 
through its role in regulating primary metabolite synthesis (Wan et al., 2015). Consequently, it is important to maximise physiological traits (Photo and Cond) over primary and secondary metabolite contents to achieve optimal yield per plant of the active component. On that note, the study deduced that growth was not affected by higher $\mathrm{N}$ rates (N60 and N90 treatments) (Ali et al., 2012). The effect of $\mathrm{N}$ on growth and physiological traits have provided insight of possible mechanism, in which pattern of photosynthetic rate against growth of $G$. procumbens. Therefore, single $\mathrm{N}$ treatment may not be the only explanation of the observed plants effects and $\mathrm{N}$ tissue status of plants especially early growth is also required (Larbat et al., 2012).

However, this study can only speculate on the plant growth including biomass are linked to $\mathrm{N}$ supplies. The highest TChlC was recorded at Week 12 (Figure 2c). Meanwhile, TChlC values are concurrent to Photo and Cond rates at Week 4 (Figure $2 \mathrm{a}$ and $2 \mathrm{~b}$ ), where gas exchange rate leaf was high, and decreased during Week 8 and subsequently increased at Week 12 . The event was because of pre-adaptation (acclimatisation), adaptation (growth) and post-adaptation (maturing) during plant growth cycle where $\mathrm{N}$ is vital component of plant energy metabolism and of activated intermediates in the photosynthetic and primary metabolism following the growth cycle requirement accordingly (Pant et al., 2015). Meanwhile, high $\mathrm{N}$ rate reported significantly decreased chlorophyll content regardless of any types of growth media (Rahimi et al., 2013). The N30 was able to produce the highest TChlC but the rate of $\mathrm{N}$ uptake was influenced by the Photo and Cond rates (Mohd Zaidan et al., 2014).

\section{CONCLUSION}

Our study shows a promising potential of E- Overall, this study showed that different amounts of $\mathrm{N}$ affect the physiological traits of $G$. procumbens. The TPDW of different $\mathrm{N}$ treatments was as follows: $\mathrm{N} 0$ (control treatment) $>\mathrm{N} 30>\mathrm{N} 60>\mathrm{N} 90$, whereas TPDW of different $\mathrm{H}$ times was Week $12>$ Week $8>$ Week 4 . The results suggest that $\mathrm{N} 0$ and N90 were highest and least, respectively, effective for enhancing growth (PH, NoL, TLA) and physiological traits (Photo, Cond and TChlC). The results also show that Photo was significantly correlated $(p \leq 0.05)$ with Cond, TPDW, NoL, TLA, and TChlC. Thus, high plant growth of $G$. procumbens should be improved through the selection of appropriate $\mathrm{N}$ rates, proper fertilizer interaction, and plant age.

\section{ACKNOWLEDGEMENTS}

The authors would like to thank the MoHE Malaysia, UNIMAS and UPM.

\section{REFERENCES}

Ali, Z., Ganie, S. H., Narula, A., Abdin, M. Z., \& Srivastava, P. S. 2012. Organic and inorganic fertilizers influence biomass production and esculin content in Cichorium intybus L. Journal of Phytology 4(5): 55-60.

An, H., \& Shangguan, Z. P. 2008. Specific leaf area, leaf nitrogen content, and photosynthetic acclimation of Trifolium repens L. seedlings grown at different irradiances and nitrogen concentrations. Photosynthetica 46(1): 143-147.

Armstrong, Donald L. 1998. Better Crops with Plant Food. (D.L. Armstrong \& K. P. Griffin, Eds.), Better Crops with Plant Food (3rd Ed.). Georgia: Potash \& Phosphate Institute.

Awang, Y., Shaharom, A. S., Mohamad, R. B., \& Selamat, A. 2009. Chemical and physical characteristics of cocopeat-based media mixtures and their effects on the growth and development of Celosia cristata. American Journal of Agricultural and Biological Science 4(1): 63-71.

Caretto, S., Linsalata, V., Colella, G., Mita, G., \& Lattanzio, V. 2015. Carbon fluxes between primary metabolism and phenolic pathway in plant tissues under stress. International Journal of Molecular Sciences 16: 26378-26394.

Chen, Y., Yu, M., Zhu, Z., Zhang, L., \& Guo, Q. 2013. Optimisation of potassium chloride nutrition for proper growth, physiological development and bioactive component production in Prunella vulgaris L. PLOS ONE $8(7): 1-7$

Davies, M. J., Atkinson, C. J., Burns, C., Woolley, J. G., Hipps, N. A., Arroo, R. R. J., Bentley, S. 2009. Enhancement of artemisinin concentration and yield in response to optimization of nitrogen and potassium supply to Artemisia annua. Annals of Botany 104: 315-323.

Galieni, A., Di Mattia, C., De Gregorio, M., Speca, S., Mastrocola, D., Pisante, M., \& Stagnari, F. 2015. Effects of nutrient deficiency and abiotic environmental stresses on yield, phenolic compounds and antiradical activity in lettuce (Lactuca sativa L.). Scientia Horticulturae 187: 93-101.

Hanudin, E., Wismarini, H., Hertiani, T., \& Sunarminto, B. H. 2012. Effect of shading, nitrogen and magnesium fertilizer on phyllanthin and total flavonoid yield of Phyllanthus niruri in Indonesia soil. Journal of Medicinal Plants Research 6(30): 4586-4592.

Heydarizadeh, P. 2016. Photosynthetic Organisms Under Stress. Universite' du Maine.

Ibrahim, M. H., Ismail, A., Omar, H., Mohd Nadzir, M. N. H., \& Mohd Zain, N. A. 2017. Primary, secondary metabolites, 
biochemical and antioxidant activity of Orthosiphon staminues Benth (Misai Kucing) under cadmium exposure. Annual Research \& Review in Biology 19(1): 1-14.

Ibrahim, M. H., Ismail, A., Omar, H., \& Zain, N. A. M. 2017. Application effects of cadmium and humic acid on the growth, chlorophyll fluorescence, leaf gas exchange and secondary metabolites in Misai Kucing (Orthosiphon stamineus) Benth. Annual Research \& Review in Biology 18(3): $1-14$.

Ibrahim, M. H., Jaafar, H. Z. E., Karimi, E., \& Ghasemzadeh, A. 2012. Primary, secondary metabolites, photosynthetic capacity and antioxidant activity of the Malaysian herb Kacip Fatimah (Labisia Pumila Benth) exposed to potassium fertilization under greenhouse conditions. International Journal of Molecular Sciences 13: 15321-15342.

Jaafar, H. Z. E., Ibrahim, M. H., \& Fakri, N. F. M. 2012. Impact of soil field water capacity on secondary metabolites, phenylalanine ammonia-lyase (PAL), maliondialdehyde (MDA) and photosynthetic responses of Malaysian Kacip Fatimah (Labisia pumila Benth). Molecules 17(6): 7305-7322.

Kaiser, D. E., Rosen, C. J., \& Lamb, J. A. 2016. Potassium for Crop Production.

Kleczewski, N. M., Herms, D. A., \& Bonello, P. 2010. Effects of soil type, fertilization and drought on carbon allocation to root growth and partitioning between secondary metabolism and ectomycorrhizae of Betula papyrifera. Tree Physiology 30: 807-817.

Larbat, R., Olsen, K. M., Slimestad, R., Løvdal, T., Bénard, C., Verheul, M., Lillo, C. 2012. Influence of repeated shortterm nitrogen limitations on leaf phenolics metabolism in tomato. Phytochemistry 77: 119-128.

Mohd Zaidan, M. W. A., Abd Shukor, S., Machap, C., Othman, S. M., \& Jaganath, I. B. 2014. Toxicological evaluation of Sambung Nyawa (Gynura procumbens) extract grown under net house condition. In A. N. Mohd Roseli, N. Osman, T. F. Ying, R. Othman, P. E. Megat Wahab, P. Ding, A. J. Zakaria (Eds.), Transactions of the Malaysian Society of Plant Physiology (Vol. 22, pp. 257-261). Kuala Terengganu: MSPPC.

Morat, N. M. 2013. Total Phenolic and Flavonoid Content of Three Species of Gynura. Universiti Teknologi MARA.

Mou, K. M., \& Dash, P. R. 2016. A comprehensive review on Gynura procumbens leaves. International Journal Of Pharmacognosy 3(4): 167-174.

Mudau, N. F., Soundy, P., \& du Toit, E. S. 2005. Plant growth and development of Bush Tea as affected by nitrogen, phosphorus, and potassium nutrition. HortScience 40(6): 1898-1901.

Mustaffa, F., Indurkar, J., Ali, N. I. M., Hanapi, A., Sha, M., Ismail, S., \& Mansor, S. M. 2011. A review of Malaysian medicinal plants with potential antidiabetic activity. Journal of Pharmacy Research 44(11): 4217-4224.

Oyedeji, S., Animasaun, D. A., Bello, A. A., \& Agboola, O. O. 2014. Effect of NPK and poultry manure on growth, yield, and proximate composition of three Amaranths. Journal of Botany 2014: 1-6.

Pal, P. K., Kumar, R., Guleria, V., Mahajan, M., Prasad, R., Pathania, V., Ahuja, P. S. 2015. Crop-ecology and nutritional variability influence growth and secondary metabolites of Stevia rebaudiana Bertoni. BMC Plant Biology 15(67): 1-16.

Pant, B. D., Pant, P., Erban, A., Huhman, D., Kopka, J., \& Scheible, W. R. 2015. Identification of primary and secondary metabolites with phosphorus status-dependent abundance in Arabidopsis, and of the transcription factor PHR1 as a major regulator of metabolic changes during phosphorus limitation. Plant, Cell \& Environment 38: 172187.
Perkasa, A. Y., Gunawan, E., Dewi, S. A., \& Zulfa, U. 2016. The testing of chicken manure fertilizer doses to plant physiology components and bioactive compound of dewa leaf. Procedia Environmental Sciences 33: 54-62.

Rahimi, A., Sayadi, F., Dashti, H., \& Tajabadi, A. 2013. Effects of water and nitrogen supply on growth, water-use efficiency and mucilage yield of isabgol (Plantago ovata Forsk). Journal of Soil Science and Plant Nutrition 13(2): 341-354.

Sekar, M., Abdullah, M. Z., Nor Azlan, A. Y. H., Nasir, S. N., Zakaria, Z., \& Abdullah, M. S. 2014. Ten commonly available medicinal plants in Malaysia used for the treatment of diabetes - A review. Asian Journal of Pharmacentical and Clinical Research 7(1): 1-5.

Selmar, D., \& Kleinwächter, M. 2013. Stress enhances the synthesis of secondary plant products: The impact of stressrelated over-reduction on the accumulation of natural products. Plant and Cell Physiology 54(6): 817-826.

Wan, H., Zhang, J., Song, T., Tian, J., \& Yao, Y. 2015. Promotion of flavonoid biosynthesis in leaves and calli of ornamental crabapple (Malus sp.) by high carbon to nitrogen ratios. Frontiers in Plant Science 6(September): 1-13.

Wang, M., Liu, H., Dong, C., Fu, Y., \& Liu, H. 2016. Elevated $\mathrm{CO}_{2}$ enhances photosynthetic efficiency, ion uptake and antioxidant activity of Gynura bicolor DC. grown in a poroustube nutrient delivery system under simulated microgravity. Plant Biology 18: 391-399.

Wuyts, N., Dhondt, S., \& Inzé, D. 2015. Measurement of plant growth in view of an integrative analysis of regulatory networks. Current Opinion in Plant Biology 25: 90-97. 